\title{
O TRIBUNAL DE CONTAS DAUNIÃO, CONTROLE HORIZONTAL DE AGÊNCIAS REGULADORAS E IMPACTO SOBRE USUÁRIOS DOS SERVIÇOS
}

\author{
Monique Menezes
}

\begin{abstract}
RESUMO
A reforma regulatória da década de 1990 apresentou profundas transformações nas relações entre as instituições brasileiras. Com a criação das agências reguladoras, uma nova governança regulatória foi estabelecida no país, com a delegação de poderes a entes autônomos para a regulação de setores fundamentais para os cidadãos. Com a inclusão de novos atores no ambiente regulatório - empresas nacionais e internacionais, novos usuários, investidores etc. -, fazem-se necessários mecanismos de transparência e prestação de contas. Com base nessas transformações, examino o papel do Tribunal de Contas da União (TCU) como instituição de accountability horizontal no controle das agências reguladoras. A análise é realizada a partir da coleta dos acórdãos da Corte de Contas, utilizando tanto pesquisa documental quanto entrevistas qualitativas com atores institucionais envolvidos nesse campo de estudo. Argumento que a atuação do TCU aumenta a legitimidade de ação das agências autônomas, na medida em que torna o processo de tomada de decisão mais transparente e democrático. Do ponto de vista do usuário, concluo que o poder de sanção do TCU tem contribuído para equilibrar a relação entre usuários e concessionárias, tendo em vista o aumento da representação das reivindicações dos cidadãos na arena regulatória. O artigo está dividido em quatro seções. Na primeira seção, a seguir, apresento a inserção do Tribunal de Contas da União no atual arranjo regulatório brasileiro e as hipóteses do artigo. Em seguida, na segunda seção, realizo uma discussão sobre os principais argumentos da literatura de delegação de poderes e accountability horizontal. Na terceira seção, há uma apresentação do desenho de pesquisa e do método utilizado neste estudo. Por fim, na quarta seção, faço uma análise de discurso de três acórdãos selecionados para este artigo com o objetivo de testar as hipóteses apresentadas na primeira seção.
\end{abstract}

PALAVRAS-CHAVE: accountability horizontal; agências reguladoras; transparência decisória; delegação; Tribunal de Contas da União.

\section{INTRODUÇÃO}

Após uma década de reforma do regime regulatório brasileiro, diversos estudos procuraram compreender o processo de criação e funcionamento das agências reguladoras

\footnotetext{
$1 \mathrm{O}$ artigo baseia-se na tese de doutorado da autora, intitulada Autonomia e controle das agências reguladoras: o papel do Tribunal de Contas da União no arranjo regulatório brasileiro, apresentada ao programa de PósGraduação em Ciência Política do Instituto Universitário de Pesquisa do Rio de Janeiro (Iuperj), em 2010. Também gostaria de agradecer aos pareceristas anônimos da Revista de Sociologia e Política por suas sugestões ao presente trabalho.
}

(MELO, 2000; BOSCHI \& LIMA, 2002; MENEZES, 2005; entre outros). As agências reguladoras são instituições autônomas e fazem parte de uma inovação institucional no arcabouço regulatório brasileiro. Foram criadas no bojo da reforma do Estado durante a década de 1990 e diferenciam-se de outras instituições burocráticas devido à existência de mecanismos institucionais que lhe conferem autonomia em relação aos políticos eleitos. O desenho dessas instituições pode variar bastante de acordo com o setor regulado, no entanto, como afirma Gillardi (2004), fundamentalmente, a criação dessas instituições tem como objetivo insular a regulação do controle político direto. 
Apesar dos estudos sobre o processo de criação e funcionamento, há poucos trabalhos que analisam o controle das instituições brasileiras de accountability horizontal sobre as agências. $\mathrm{O}$ modelo de agência reguladora autônoma tem suscitado a discussão dos riscos que esse desenho institucional representa para a democracia representativa. Segundo Diniz (2001), a centralização decisória em burocracias insuladas do controle político enfraquece os suportes institucionais democráticos, ou seja, o controle mútuo entre os três poderes e o controle social do público em geral sobre as atividades do Estado. A grande dicotomia coloca-se entre autonomia e controle: como garantir autonomia e ao mesmo tempo controlar?

O pressuposto ideológico desse desenho institucional consiste em que os critérios de eficácia, eficiência e de adequação técnica devem sobrepor-se às decisões políticas de justiça relativa entre grupos da sociedade, por exemplo, de modo a proporcionar um ambiente de mercado favorável aos investimentos. Daí a necessidade de reformar o arcabouço regulatório prévio e conferir autonomia às instituições reguladoras ante os políticos eleitos. Desse ponto de vista, a accountability e os mecanismos de transparência e controle são centrais para uma atuação legítima das agências. Sem uma definição clara desses mecanismos, a delegação de autoridade perde seu sentido, na medida em que pode ocorrer um comportamento oportunista por parte dos dirigentes dessas agências e a delegação passa a ser abdicação do poder por parte dos políticos eleitos (KIEWIET \& MCCUBBINS, 1991).

No Brasil, as atividades antes exercidas diretamente pelo poder Executivo foram transferidas para empresas privadas e o controle dos agentes econômicos foi delegado a uma burocracia autônoma. Além da mudança na estrutura formal de decisões, também houve a inclusão de novos atores no ambiente regulatório: empresas nacionais e internacionais, usuários dos serviços de utilidade pública, investidores, entre outros. Como esses atores possuem interesses conflitantes, também se faz necessária a elaboração de mecanismos de transparência do processo de tomada de decisões e de um sistema de ampla prestação de contas dos reguladores. Esses dispositivos proporcionam uma arena regulatória confiável e previsível, tanto do ponto de vista do usuário quanto do investidor. Essas modificações na governança regulatória demandam um reordenamento dos antigos instrumentos de accountability, com inovações institucionais que necessariamente variam entre os países, de acordo com as trajetórias específicas do sistema político e da cultura nacional.

A questão teórica mais central dessa literatura retoma o debate weberiano sobre os desafios decorrentes da delegação de poderes feita por políticos eleitos a "experts" (MELO, 2001). Em termos empíricos, a reforma regulatória levanta as questões que se seguem: $i$ ) como fornecer autonomia às agências e, ao mesmo tempo, controlar suas atividades? ii) como operacionalizar efetivamente os mecanismos de accountability e transparência (LODGE, 2004); iii) para quem a agência reguladora deve ser accountable (idem)?

Nesse contexto, o objetivo deste artigo é analisar o efeito do controle externo horizontal exercido pelo Tribunal de Contas da União (TCU) sobre as atividades das agências reguladoras brasileiras federais. O'Donnell (1994) classifica e qualifica a accountability em dois níveis: horizontal e vertical. Esta última refere-se às ações realizadas, por grupos ou indivíduos, que afetam aqueles que ocupam posições em instituições do Estado, eleitos ou não. Nessa definição, as eleições constituem um importante mecanismo de accountability vertical, na qual os cidadãos podem reeleger ou destituir os políticos. A segunda definição apresentada pelo autor, accountability horizontal, consiste na existência de agências estatais que possuem o direito e o poder legal para a realização de ações de supervisão de rotina e a imputação de sanções legais sobre outras agências do Estado. Nesse caso, as instituições de supervisão tem poder de controle sobre as demais, com a possibilidade de impor sanções.

Este artigo centrará suas análises na accountability horizontal realizada pelo Tribunal de Contas da União sobre as agências reguladoras federais. Especificamente, será observado o efeito das auditorias sobre a qualidade da regulação para os usuários dos setores regulados. O artigo está dividido em quatro seções. Na primeira seção, a seguir, apresento a inserção do Tribunal de Contas 
da União no atual arranjo regulatório brasileiro e as hipóteses do artigo. Em seguida, na segunda seção, realizo uma discussão sobre os principais argumentos da literatura de delegação de poderes e accountability horizontal. Na terceira seção, há uma apresentação do desenho de pesquisa e do método utilizado neste estudo. Por fim, na quarta seção, faço uma análise de discurso de três acórdãos selecionados para este artigo com o objetivo de testar as hipóteses apresentadas na primeira seção.

\section{O TRIBUNAL DE CONTAS E O NOVO MODELOREGULATÓRIOBRASILEIRO}

A partir do processo de aprofundamento da desestatização, caracterizado pel a privatização das empresas estatais, o TCU reinterpretou seu mandato constitucional, adaptando-se aos novos arranjos regulatórios do Estado brasileiro, transformando-se em um dos principais órgãos de fiscal ização das agências regul adoras federais. O Tribunal vem realizando diversas auditorias sobreas atividades fins ${ }^{2}$ das agências reguladoras, ou seja, acerca do conteúdo específico da regulação emitida e dos procedimentos adotados para a regulação dos setores. O principal objetivo dessas auditorias consiste em verificar se as agências reguladoras estão exercendo seu mandato de maneira eficaz e em conformidade com a legislação brasileira. As auditorias resultam em recomendações e determinações do Tribunal aos entes regulatórios. As determinações podem apresentar decisões contrárias às medidas tomadas pela agência ou alguma solicitação de esclarecimentos, que precisam ser implementadas ou respondidas pelo regulador em até 90 dias. Por outro lado, as recomendações não possuem caráter obrigatório para a instituição que está sofrendo a fiscalização da Corte de Contas.

O amplo mandato do Tribunal em realizar determinações e recomendações sobre as "atividades fins" das agências reguladoras tem

2 Destaque-se que os termos "auditoria operacional" e "auditoria das "atividades fins" sobre as agências reguladoras são tratados, neste trabalho, como sinônimos. Ambos referem-se à fiscalização dos métodos adotados pela agência para o cumprimento do seu mandato na regulação dos setores de infraestrutura, envolvendo análise de eficiência, de economicidade e de legalidade dos seus atos. gerado três tipos de críticas, a saber: falta de legitimidade, aumento de insegurança regulatória e sobreposição de poderes. Primeiro, alguns autores têm argumentado que não cabe ao Tribunal fiscalizar as atividades fins dessas agências e que a sua fiscalização deve ser somente financeira (BARROSO, 2006). Por rever as decisões das agências, em segundo lugar, argumenta-se também que a atuação do TCU pode afetar a segurança jurídica do regime regulatório, uma vez que diminui a previsibilidade da regulação (GOMES, 2006). Terceiro, entende-se que a fiscalização da Corte de Contas causa uma superposição de controles, uma vez que o objetivo das agências é controlar as concessionárias, que recebem uma delegação para prestarem serviços públicos (idem). Nesse sentido, estaria na esfera de atuação das agências, e não do TCU, o acompanhamento dos contratos de concessão, por exemplo.

Entretanto, a literatura neoinstitucionalista argumenta que o estabelecimento de instituições dotadas de autonomia para exercer a regulação de setores não elimina o envolvimento de instituições tradicionais existentes antes da reforma regulatória (JORDANA \& SANCHO, 2004). As funções de atores tradicionais (ministérios, poder Judiciário, poder Legislativo, poder Executivo e instituições de accountability horizontal) são redefinidas, tornando-se o que Jordana e Sancho (idem) denominam de um "produto" do legado de pathdependence.

No Brasil, o Tribunal de Contas sempre fiscalizou as empresas de utilidade pública por tratar-se de um regime de propriedade estatal. Esse controle centralizava-se nas dimensões jurídica, formal e financeira. Com a reforma do Estado, o TCU adaptou suas funções fiscalizadoras com base na Constituição de 1988, mantendo sua atuação nos setores de infraestrutura, que já eram fiscalizados. Desse modo, a reforma regulatória gerou um controle adicional não previsto por seus formuladores, a accountability horizontal da Corte de Contas, sobre os entes regulatórios.

Além de sua capacidade explicativa acerca do impacto das mudanças institucionais na atuação dos atores com a reforma regulatória, as teorias neoinstitucionalistas também nos permitem compreender as principais motivações para a realização da reforma regulatória (GILARD, 
2004). De acordo com os autores do institucionalismo da escolha racional, as agências reguladoras autônomas foram implementadas em diversos países com o objetivo de aumentar a credibilidade regulatória dos setores privatizados e resolver o problema de incerteza política, natural ao sistema democrático (idem). Nesse sentido, para essa corrente do neoinstitucionalismo, a atuação de uma instituição de controle horizontal pode aumentar a incerteza da política regulatória, introduzindo um segundo agente revisor das decisões da agência.

Neste artigo, entretanto, argumento no sentido oposto, ou seja, de que a atuação do Tribunal de Contas aumenta a credibilidade e a segurança da política regulatória, uma vez que inibe um possível comportamento oportunista do regulador.

A partir do exposto, as hipóteses de trabalho são: $i$ ) a atuação fiscalizadora do TCU aumenta a segurança regulatória, tendo em vista que o órgão inibe o possível comportamento oportunista e discricionário das agências reguladoras, fiscalizando normativamente seus atos. O Tribunal atua na garantia da legalidade e do interesse público como um ator de veto à excessiva discricionariedade do regulador e não na formulação propositiva de conteúdo regulatório; ii) a atuação do TCU confere maior legitimidade às ações das agências reguladoras, uma vez que se trata de um órgão de controle horizontal, vinculado ao Congresso Nacional; iii) as características institucionais do TCU - sua constituição pelo poder Legislativo, que representa todos os segmentos da população, e seu caráter de corpo burocrático, que visa o cumprimento da lei - fazem que ele atue sobre o conteúdo da regulação emitido pelas agências reguladoras de maneira mais universalista, aumentando a representação dos cidadãos-usuários na regulação das agências reguladoras autônomas.

Do ponto de vista dos usuários-cidadãos, o argumento deste artigo é que as diferenças institucionais entre o TCU e as agências reguladoras permitem-nos supor a existência de incentivos institucionais distintos para o resultado das regras regulatórias. As agências são instituições que possuem diretores nomeados pelo poder Executivo com mandatos com tempo determinado e que priorizam a tecnicidade em suas decisões. Por outro lado, o TCU é um órgão auxiliar do poder Legislativo. Seus ministros são nomeados pelo Congresso para mandatos vitalícios e, embora possua um corpo técnico qualificado, prioriza o cumprimento da lei em detrimento de questões técnicas de um mercado específico. Tendo em vista o caráter universalista da lei, princípio da atuação do TCU, considero que é maior a probabilidade de o TCU equilibrar as regras em favor de um acordo mais justo entre os usuários e as empresas, se comparado às agências reguladoras, cujo objetivo constitucional é manter o equilíbrio econômico e operacional do setor regulado.

No que se refere à segurança regulatória, o argumento consiste em que o TCU inibe um possível comportamento oportunista das agências reguladoras e diminui as chances de "captura" dessas instituições pelas empresas dos setores regulados. Sua atuação é benéfica, por exemplo, para empresas que desejam entrar em um setor já estabelecido, na medida em que o Tribunal fiscaliza as ações normativas das agências que podem ser influenciadas pelas empresas já estabelecidas em dado setor. Dessa forma, em vez de contribuir para o aumento da insegurança jurídica, sua atuação amplia a credibilidade das regras regulatórias, tendo em vista que o processo de fiscalização aumenta a transparência dos procedimentos regulatórios.

Por fim, no que se refere à possibilidade de superposição de controles, é importante destacar que o desenho institucional do Estado brasileiro, de fato, permite a existência de controles mútuos, "checks and balances". Esse arcabouço institucional possui como objetivo evitar a concentração de poder nas mãos de um único órgão, criando instituições concorrentes que agem limitando uma às outras. Apesar disso, o TCU não substitui o papel delegado à agência reguladora de regular os setores privatizados. A iniciativa regulatória na definição dos aspectos técnicos e equilíbrios econômicos do setor ainda são da agência. No entanto, em suas auditorias, o TCU procura verificar a conformidade com a lei e os princípios de interesse público que a fundamentam. Se for observada alguma irregularidade, o órgão, em seu papel fiscalizador de revisão dos procedimentos adotados e critérios utilizados pela agência, pode determinar a agência que revise seus atos, no sentido do cumprimento da legislação brasileira, não se tratando de uma sobreposição, mas sim de controle horizontal. 
III. PROBLEMAS DEDELEGAÇÃO ÀS AGÊNCIAS REGULADORAS E OS MECANISMOS DE ACCOUNTABILITY HORIZONTALDO REGIME REGULATÓRIO

A relação entre os políticos eleitos e a burocracia especializada a quem os primeiros delegam poderes para a implementação de políticas públicas é um tema em aberto na teoria política. A longa tradição do sistema político estadunidense de delegar autoridade às agências reguladoras resultou em um amplo debate acadêmico nesse país, com a produção de uma vasta literatura sobre a relação entre os políticos eleitos e a burocracia.

A literatura americana argumenta na direção de que, em democracias modernas represen-tativas, a delegação de poderes é inevitável (KIEWIET \& MCCUBBINS, 1991; PRZEWORSKI, 2003). Os eleitores, por meio das eleições, delegam autoridade aos seus repre-sentantes. No caso de regimes presidencialistas, a representação ocorre por meio de dois poderes independentes: o poder Legislativo e o poder Exe-cutivo. A rede de delegação continua: o presidente delega poderes aos seus ministros e à burocracia e, ao mesmo tempo, o Congresso incumbe, inter-namente, funções às suas comissões especializadas e aos líderes partidários e, externamente, à burocracia.

Nesse contexto de delegação do sistema político, a execução da política pública é realizada por meio da ação coletiva dentro de cada poder e entre eles (KIEWIET \& MCCUBBINS, 1991). O Congresso precisa organizar-se para o aperfeiçoamento da legislação e supervisionar a burocracia, a quem ele delega poderes. Para implementar sua política de governo, o poder Executivo deve coordenar seus ministros junto à burocracia, que também é subordinada aos membros do Congresso Nacional. Por fim, ambos, poder Executivo e Congresso, devem considerar o poder Judiciário em suas ações, quando este possui poder revisor, cujo objetivo normativo é prevenir abusos do poder público, praticados pelos políticos eleitos ou pela burocracia (PRZEWORSKI, 2003).

O processo de delegação aqui descrito representa um complexo de relações hierárquicas. Para um melhor entendimento dessas relações, a Ciência Política utiliza a "teoria da agência" ou principal-agent model ${ }^{3}$, desenvolvida a partir da

3 Neste artigo, a expressão principal-agent será traduzida para "mandante-mandatário". De acordo com o Dicionário análise organizacional de empresas privadas. Esse modelo de análise possui o objetivo de esclarecer problemas de controle hierárquico quando há conflito de interesses e assimetria de informações (MOE, 1984).

De acordo com Kiewiet e McCubbins (1991), a delegação de poderes por um indivíduo ou instituição (mandante), que foi originalmente incumbido de uma tarefa, para outro sujeito (mandatário) caracteriza a relação mandantemandatário. Em termos gerais, o modelo de delegação requer, no mínimo, dois atores: o mandante e o mandatário. O mandatário é sempre o primeiro a agir, propondo uma alternativa ao status quo. Em seguida, o mandante possui a opção de aceitar a proposta ou de rejeitá-la em favor do status quo.

O problema da delegação, como apontado por Lupia e McCubbins (1998), refere-se à assimetria de informação e ao conflito de interesses entre o mandante e o mandatário. Em geral, dada a sua natureza política e não técnica, o mandante carece de informações precisas para avaliar se as ações do mandatário estão ou não de acordo com os seus interesses. Por possuir informações privilegiadas, que não estão disponíveis ao mandante, o mandatário pode realizar ações de seu interesse, em detrimento do interesse do mandante. Dessa forma, esta constitui-se uma relação naturalmente conflituosa, gerando dois tipos de problemas denominados pela literatura de "perdas de agência" (agency losses).

Primeiro, o mandatário pode, sistematicamente, optar por ações que sejam contrárias aos desejos do mandante. Segundo, para garantir o cumprimento de seus interesses, o mandante precisa criar mecanismos de controle que demandam recursos significativos. Neste último caso, o custo para monitorar as ações do mandatário pode tornar-se elevado demais, ao ponto de a delegação de poderes deixar de ser eficiente para o mandante. Lupia e McCubbins (idem) argumentam que, na ausência de mecanismos de controle, a delegação torna-se uma abdicação do poder. Assim, a delegação é bem sucedida somente se as ações do mandatário aumentar as condições de bem-estar do mandante.

Aurélio Século XXI, o mandante é a pessoa que outorga um mandato a outrem, chamado, dessa forma, de mandatário. 
Consequentemente, a delegação falha quando as ações do mandatário são contrárias ao interesse do mandante.

As informações assimétricas e os conflitos de interesses tornam-se mais crônicos quando há situações de múltiplos mandantes e múltiplos mandatários, como é o caso específico da delegação política que envolve a burocracia, o Congresso, o poder Executivo e os eleitores. Por exemplo, as agências reguladoras são mandatários do poder Executivo e do Congresso. Assim, suas ações podem beneficiar um de seus mandantes e, simultaneamente, contrariar os interesses do outro. Além disso, quando há múltiplos mandatários, podem ocorrer situações de conluio contra os mandantes, devido à especialização da burocracia (MOE, 1987; WEINGAST, 2005).

Alguns autores norte-americanos que estudam a relação entre o Congresso e a burocracia deste país, como Lowi (1979), argumentam que a delegação de autoridade para agências regulatórias resulta sempre em uma abdicação, por parte dos políticos eleitos, de suas responsabilidades. De acordo com o autor, inicialmente, a delegação para as Comissões Regulatórias norte-americanas era mais limitada e definida, não sendo caracterizada por abdicação. No entanto, progressivamente, o Congresso americano delegou mais atividades de elaboração de políticas públicas às agências reguladoras, aumentando o poder discricionário dessas instituições no sistema político do país. Dessa forma, a falha dessa ampla delegação consiste em que, para o autor, o Congresso não possui capacidade de controle sobre essa burocracia.

Embora, em teoria, os políticos eleitos possam inserir mecanismos de accountability no sistema de delegação, tendo em vista que são os responsáveis pelas regras de atuação da burocracia, Fisher (1981) afirma que a natureza dos mecanismos de delegação impede uma ampla supervisão dos políticos acerca da elaboração ${ }^{4} \mathrm{e}$ da implementação das políticas públicas. Fiorina (1981) acrescenta o problema da natureza dos incentivos para os congressistas engajarem-se no controle efetivo da burocracia. De acordo com o

\footnotetext{
4 Em alguns casos, a legislação de um setor é muito geral, permitindo que a agência tome a iniciativa para a elaboração da política pública.
}

autor, os benefícios resultantes da supervisão sobre a burocracia são bens públicos, enquanto os parlamentares podem auferir ganhos políticos maiores defendendo matérias que produzam bens privados e com maior visibilidade, particularmente em um congresso com poder decisório descentralizado como o norte-americano. Essa situação inverte-se apenas em momentos em que a burocracia está em evidência para a sociedade.

Apesar das críticas elaboradas por parte da literatura americana, Lupia e McCubbins (1998) sustentam que, sob certas condições específicas, a delegação de poderes dos políticos eleitos à burocracia pode ser bem sucedida. Para os autores, a crítica da literatura, de que a delegação de poderes para a burocracia sempre resulta em falhas, não considera a possibilidade de aprendizado e adaptação do mandante ao problema de limitação de informações. De acordo com os autores, as perdas geradas pela assimetria de informação podem ser superadas, possibilitando que as ações da burocracia sejam alinhadas aos interesses dos políticos eleitos e dos eleitores.

A legitimidade da atuação das agências reguladoras vem ganhando destaque entre os estudiosos da América Latina e da Europa, sobretudo após a difusão do modelo norteamericano nessas regiões. Embora o controle político dessas instituições tenha se mostrado um problema crítico para as democracias modernas, Weingast (2005) sustenta, assim como Kiewiet e McCubbins (1991), que os políticos eleitos possuem ferramentas e procedimentos com os quais eles podem influenciar e controlar as escolhas de uma agência. Para esses autores, controlar a burocracia não significa que os políticos devam gastar tempo, esforços e recursos, diretamente. Ao contrário, os mandantes devem utilizar um conjunto de incentivos e mecanismos para controlar as ações do mandatário. A seguir, detalharemos alguns desses mecanismos apontados pela literatura.

\section{III.1. Controle ex ante}

$\mathrm{O}$ controle ex ante sobre as agências reguladoras pelos políticos são limitações inseridas no desenho institucional da própria burocracia que se pretende controlar. Esses obstáculos são inseridos no momento de sua criação ou, posteriormente, por meio de legislação complementar, com o objetivo institucional de evitar desvios de conduta do mandatário, ou seja, 
obrigando-o a agir de acordo com o interesse do mandante.

De acordo com Weingast (2005), o detalhamento formal dos procedimentos de tomada de decisão das agências reguladoras diminui a probabilidade de conluios e a possibilidade de desvio de objetivos por parte do mandatário. $\mathrm{O}$ autor alega que mecanismos de transparência auxiliam no controle sobre a burocracia pelo mandante, criando incentivos para o mandatário comportar-se de acordo com os interesses daquele. A legislação deve, dessa forma, especificar o processo de decisão da burocracia, como uma nova regra de regulação deve chegar ao conhecimento do público interessado e como deve ser o processo de participação da sociedade na tomada de decisão da agência reguladora. Como exemplo, o autor utiliza o Administrative Prodecure Act, de 1946, que delimitou e padronizou os procedimentos administrativos das agências reguladoras norte-americanas.

A determinação de resultados mínimos a serem alcançados pela agência reguladora também se constitui em um controle ex ante. No Brasil, algumas agências reguladoras, entre as quais a Agência Nacional de Energia Elétrica (Aneel), possuem um Contrato de Gestão, em que o poder Executivo define metas anuais de desempenho da instituição. Para esse tipo específico de controle, Kiewiet e McCubbins (1991, p. 27) argumentam que não há legislação ou contrato que possa prever todas as situações e procedimentos de um mandatário. Para os autores, dificilmente o mandante pode mensurar os resultados da política pública de uma agência reguladora, uma vez que não há parâmetros para comparação de desempenho da burocracia e que o mandante não possui especialização no tema delegado. Przeworski (2003) também argumenta na mesma direção, enfatizando que o monopólio de uma burocracia impede comparações de desempenho, como ocorre na iniciativa privada.

\section{III.2. Controles ex post}

Em oposição ao controle ex ante, os mecanismos de controle ex post são desenhados para que os políticos eleitos reajam, após a tomada de decisão das agências reguladoras.

De acordo com Przeworski (2003), toda democracia representativa pode ser estruturada de tal forma que as burocracias responsáveis pela tomada de decisões sejam adversárias dentro do governo, gerando uma interação entre múltiplos mandatários com objetivos distintos. Assim, a construção da rede de delegação pode contar com mecanismos institucionais de accountability horizontal, de modo que a delegação de poderes a um mandatário possua, no mínimo, um outro mandatário com autoridade para vetar ou bloquear as ações do primeiro, caso isto seja necessário (KIEWIET \& MCCUBBINS, 1991; PRZEWORSKI, 2003).

Esse tipo de controle pode ser realizado por dois caminhos. Primeiro, entre os poderes, o poder Legislativo supervisiona as ações da burocracia vinculada diretamente ao poder Executivo e vice-versa. Segundo, pela própria burocracia do Estado, distintos órgãos da burocracia podem receber poder de sanção sobre outras. Para este último caso, o controle institucional só é desejável quando os mandatários possuem incentivos para serem conflitivos. Caso contrário, podem ocorrer situações de conluio entre as burocracias. Kiewiet e McCubbins (1991) apontam que o controle institucional inibe que um mandatário realize ações indesejadas pelo mandante, mas também protela ações desejáveis por este. Assim, uma consequiência negativa para o setor regulado pode ser a dificuldade em realizar mudanças, quando há múltiplos grupos de vetos, ou seja, agentes com poder de veto (COX \& MCCUBBINS, 2001).

O controle dos políticos também pode ser realizado por meio de supervisão direta das atividades das agências, por meio de relatórios anuais e auditorias. Esse tipo de controle é caracterizado pelo monitoramento constante da burocracia pelo Congresso. Em geral, o parlamento de qualquer país pode realizar auditorias investigativas sobre as agências reguladoras. Na Inglaterra, por exemplo, o National Audit Office (NAO) órgão equivalente ao TCU brasileiro, auxilia o parlamento inglês na fiscalização de todos os órgãos públicos, inclusive as agências reguladoras (BOURN, 2005).

Segundo Weingast, os políticos eleitos preferem controlar a burocracia utilizando mecanismos que minimizem esforço, tempo e recursos, para se dedicarem ao seu mandato político específico. Para Kiewiet e McCubbins (1991), como o congresso recebe todos os anos milhares de relatório das burocracias, 
apresentando as atividades de audiências e consultas públicas, investigações e recomendações, o consumo de toda essa informação demanda muito recurso pessoal da elite política. Os políticos eleitos precisariam ler, detalhadamente, relatórios sobre temas que eles não possuem domínio técnico para julgar o teor das informações. Além disso, como são relatórios produzidos pelas próprias instituições, o conteúdo das informações não é totalmente confiável, na medida em que, nenhuma burocracia destacaria seus pontos fracos.

A partir dessas críticas ao controle conhecido como "patrulha policial" (police patrol) das agências reguladoras e da burocracia como um todo, McCubbins e Schwartz (1984) argumentam que o controle efetivo ocorre apenas quando há o "elemento surpresa". Nesse caso, em vez de examinar centenas de relatórios, o mandante pode acionar uma terceira parte, com o objetivo de fazê-la funcionar como um "alarme de incêndio" (fire alarm). Como terceira parte, entende-se aqui a imprensa, as empresas reguladas e os usuários de um serviço, que possuam interesses conflitantes.

De acordo com os autores, o mecanismo de alarme de incêndio apresenta vantagens sobre as demais formas de controle. O custo para obterem as informações é menor, uma vez que o mandante não precisa despender tempo sobre centenas de relatórios. A qualidade dos dados também é melhor, já que o mandante, ao examinar os relatórios das agências, pode não notar desvios importantes cometidos pelo mandatário, enquanto, por meio do mecanismo de alarme de incêndio, as terceiras partes apontam problemas específicos na atuação do mandatário, enterrados entre as informações dos diversos relatórios e prestações de contas.

Note-se que, para o funcionamento do controle de alarme de incêndio, faz-se necessária a existência de mecanismos transparentes e efetivos. Somente com a ampla divulgação das decisões das agências reguladoras, uma terceira parte, sobretudo fora do aparato estatal, pode acionar os políticos eleitos. É nesse ponto que se concentram as principais críticas acerca do mecanismo de controle discutido por McCubbins e Schwartz. Para Aberbach (1990), o controle da burocracia, exclusivamente por meio do sistema de alarme de incêndio, beneficiaria raros cidadãos, bem articulados, com alto interesse pelas ações da burocracia e os grupos de interesse organizados.

No que se refere à fiscalização do Congresso Nacional brasileiro, a literatura destaca a existência de poucos mecanismos de controle disponíveis ao poder Legislativo para a fiscalização das agências reguladoras. Diniz (2001) argumenta que o modelo de gestão tecnocrata aliado às amplas prerrogativas do poder Executivo brasileiro enfraquece os mecanismos de controle do Congresso e, ao mesmo tempo, fortalece ainda mais o poder Executivo. A falta de obrigatoriedade de qualquer tipo de prestação de contas das agências diretamente ao congresso é uma crítica consolidada pela literatura brasileira (BOSCHI \& LIMA, 2002; SALGADO, 2003; MENEZES, 2004; SALGADO \& MOTTA, 2005; OCDE, 2008, entre outros). Embora os congressistas não possuam incentivos para usá-los, deve-se destacar que há mecanismos disponíveis para o controle das agências pelo poder Legislativo.

O controle ex post do Congresso Nacional pode ser realizado por meio das comissões parlamentares que se dividem em funções legislativas e fiscalizadoras e podem ser auxiliadas pelo TCU. O trabalho das comissões do congresso de fiscalização exerce um controle de monitoramento, o que McCubbins e Schwartz (1984) denominaram "patrulha policial". No Brasil, essa forma de controle ocorre esporadicamente pelo Congresso brasileiro. O problema, como apontado por Fiorina (1981), é que a "patrulha policial" demanda muito tempo e recursos, ao mesmo tempo em que apresenta poucos retornos políticos para os congressistas.

Além do controle direto dos parlamentares, as agências também podem ser fiscalizadas pela Corte de Contas, por meio de auditorias independentes, sem que seja necessária a solicitação de um membro ou comissão do Congresso Nacional. O TCU é uma instituição criada ainda pela Constituição Imperial, em 1824, cujo objetivo inicial limitava-se à fixação das contas públicas anuais. Durante o século XIX, o seu mandato institucional foi gradativamente ampliado ${ }^{5}$. A Constituição Federal de 1988 introduziu mudanças substanciais acerca do papel do TCU, incluindo

5 Para uma análise detalhada das mudanças institucionais do TCU, desde sua criação, ver Pessanha (1997). 
em seu mandato, além da auditoria financeira, aspectos de efetividade, de eficiência e de economicidade dos gastos públicos. De acordo com Pessanha (1997), a fiscalização operacional e patrimonial, em conjunto com o conceito de "economicidade", supera a idéia de uma auditoria focada apenas nos gastos, caminhando para uma auditoria da qualidade desses dispêndios.

O controle desempenhado hoje pelo TCU pode ser classificado de duas formas. Primeiro, como uma forma tradicional de accountability horizontal, na medida em que ambos, o TCU e a agência, são mandatários do Congresso. O mandato do Tribunal permite que ele bloqueie as ações das agências, desde que, na sua interpretação, as decisões dessas instituições estejam em desacordo com o seu mandato. Segundo, o controle do TCU também pode ser interpretado como um tipo de "alarme de incêndio", tendo em vista que a Corte de Contas possui iniciativa própria para realizar suas auditorias, sejam elas sobre as agências reguladoras, sejam elas sobre outros órgãos federais. Dessa forma, o Congresso não precisa gastar recursos acompanhando o trabalho de auditoria; pode, como argumentado por McCubbins e Schwartz (1984), reagir a uma ação das agências reguladoras a partir das auditorias realizadas pelo TCU. Nesse caso, somente as auditorias com maiores repercussões na sociedade atrairão a atenção dos congressistas.

Apenas como ilustração, a Tabela 1, a seguir, apresenta os atores institucionais que iniciaram uma auditoria sobre os setores de telecomunicações, energia e petróleo no período de 1993 a 2009. Como pode ser observado, entre os atores institucionais listados na tabela, o TCU foi responsável por $83,56 \%$ das auditorias coletadas $^{6}$. É interessante observar que o Congresso Nacional demandou, entre as auditorias de interesse da pesquisa, apenas $11,64 \%$ das fiscalizações, demonstrando uma ampla autonomia do Tribunal.

6 Os acórdãos selecionados para a pesquisa referem-se somente à fiscalização de conteúdo da regulação. Não foram coletados acórdãos referentes à auditoria de contas. Alguns acórdãos selecionados antes da criação das primeiras agências reguladoras versam sobre temas como a privatização dos setores.
TABELA 1 - ATOR QUE INICIOU A AUDITORIA

\begin{tabular}{|lcc|}
\hline ATOR & $\boldsymbol{N}$ & $\%$ \\
\hline TCU & 244 & 83,56 \\
Congresso Nacional & 34 & 11,64 \\
Poder Executivo & 3 & 1,03 \\
Anônimo & 2 & 0,68 \\
Parlamentar & 2 & 0,68 \\
TCU e MP & 2 & 0,68 \\
Usuário de setor regulado & 2 & 0,68 \\
Prefeituras & 1 & 0,34 \\
Partido Político & 1 & 0,34 \\
Secretaria Governamental & 1 & 0,34 \\
Total & 292 & 100 \\
\hline
\end{tabular}

FONTE: Menezes (2010).

A diferença entre o Congresso e a Corte de Contas é bastante acentuada quando observamos as suas iniciativas de auditoria pela clivagem entre temas sociais e econômicos. A fiscalização do Tribunal concentra-se na regulação econômica, com $91,4 \%$, enquanto, entre as auditorias solicitadas pelo Congresso, esse percentual cai para $61,8 \%$. É importante destacar que essa distinção entre regulação econômica e social é muito tênue e que a maior parte das ações regulatórias envolve ambas as áreas. Nesse caso, o importante é observar como os congressistas brasileiros comportam-se na direção do que indica a literatura, preocupando-se com a fiscalização de temas que podem resultar em ganhos políticos como argumentado por Fiorina (1981).

TABELA2 - TIPO DE REGULAÇÃO PORATOR QUE INICIOU AAUDITORIA

\begin{tabular}{|lcccc|}
\hline \multirow{2}{*}{ ATOR } & \multicolumn{4}{|c|}{ TIPO DE REGULAÇÃO } \\
\cline { 2 - 5 } & & ECONÔMICA & SOCIAL & TOTAL \\
\hline \multirow{2}{*}{ TCU } & $N$ & 223 & 21 & 244 \\
& $\%$ & 91,4 & 8,6 & 100,0 \\
Congresso & $N$ & 21 & 13 & 34 \\
Nacional & $\%$ & 61,8 & 38,2 & 100,0 \\
\multirow{2}{*}{ Total } & $N$ & 244 & 34 & 278 \\
& $\%$ & 87,8 & 12,2 & 100,0 \\
\hline
\end{tabular}

FONTE: Menezes (2010).

NOTA: Probabilidade de $\mathrm{H}_{0}$ do teste de significância do $X^{2}=0,00$. 


\section{DESENHO DE PESQUISA}

Atualmente, o Brasil conta com dez agências reguladoras autônomas federais, nos setores de energia elétrica, telecomunicações, petróleo, saúde suplementar, saúde sanitária, água, cinema e transportes terrestre, pluvial e aéreo. Dentre essas agências, nove foram criadas durante o primeiro e o segundo mandatos do ex-Presidente Fernando Henrique Cardoso e uma (a de aviação civil) durante o primeiro mandato do ex-Presidente Luís Inácio Lula da Silva.

As análises empíricas desta seção focaram apenas as agências de energia e telecomunicações, Aneel e Agência Nacional de Telecomunicações (Anatel), respectivamente. A existência de outras agências reguladoras federais em operação no país torna imperativa a justificativa para a escolha dessas duas instituições.

O Tribunal de Contas realizou suas primeiras fiscalizações sobre Aneel, Anatel e Agência Nacional de Petróleo, Gás Natural e Biocombustíveis (ANP). Com o objetivo de entender o novo contexto regulatório brasileiro, o TCU realizou sua primeira auditoria de conteúdo sobre essas três instituições. Essa primeira fiscalização não foi centrada em aspectos específicos dos setores, mas sim no ordenamento interno e no mandato de cada agência. Apesar disso, optei por concentrar as análises apenas nas agências de energia e de telecomunicações, excluindo a de petróleo, tendo em vista a maior interação com os usuários por aquelas duas agências. Assim, além de uma maturidade institucional maior, já que foram as primeiras agências a serem criadas, a Aneel e a Anatel apresentam mais elementos analíticos para os objetivos do artigo, centrado no impacto da atuação do Tribunal sobre os usuários dos serviços regulados.

Foram selecionados três casos de auditoria do TCU, em que avaliei o impacto da atuação da Corte de Contas sobre o conteúdo regulatório dos setores regulados, mais especificamente seu impacto sobre os usuários dos setores de energia e telecomunicações. Com o objetivo de entender a influência do TCU sobre a arena regulatória, a análise dos acórdãos desdobrar-se-á nas seguintes perguntas: $i$ ) as recomendações ou determinações resultam no aperfeiçoamento das regras do setor regulado a partir da maior garantia da lei e do interesse público? ii) As auditorias procuram inibir uma possível discricionariedade excessiva das agências, que poderia ser objeto de captura regulatória, aumentando, assim, a segurança jurídica da arena regulatória? iii) Há considerações que contrariam a decisão da agência reguladora visando a garantia do direito dos usuários e o interesse público? iv) A auditoria do TCU aumenta a transparência do processo regulatório?

A Tabela 3, a seguir, apresenta os acórdãos que foram analisados neste estudo de caso. Para além da distribuição das características dos acórdãos selecionados, é importante ressaltar que eles foram escolhidos também segundo o seu impacto no setor. As auditorias incluídas na análise apresentaram grande impacto na definição do conteúdo regulatório do seu respectivo setor. É possível imaginar a existência de um viés associado a esta seleção, na medida em que os acórdãos de menor impacto apresentem padrões de respostas diferentes às perguntas que nortearam esta análise, mas isto, apesar de verdadeiro, é pouco relevante. Simplesmente porque os temas são, eles próprios, menos relevantes.

TABELA 3 - ACÓRDÃOS SELECIONADOS PARAAANÁLISE DE IMPACTO DO TCU 7

\begin{tabular}{|l|l|c|c|c|c|c|}
\hline & SETOR & $\begin{array}{c}\text { No DO } \\
\text { ACÓRDÃO/ANO }\end{array}$ & $\begin{array}{c}\text { ATOR QUE } \\
\text { INICIOU A } \\
\text { AUDITORIA }\end{array}$ & $\begin{array}{c}\text { TIPO DE } \\
\text { AUDITORIA }\end{array}$ & TEMA & $\begin{array}{c}\text { ATOR } \\
\text { AUDITADO }\end{array}$ \\
\hline 1 & Telecomunicações & $1778 / 2004$ & TCU & Operacional & $\begin{array}{c}\text { Universalização } \\
\text { de Serviços }\end{array}$ & Anatel \\
2 & Energia Elétrica & $1066 / 2001$ & TCU & Operacional & Tarifas & Aneel \\
3 & Energia Elétrica & $\begin{array}{c}649 / 2005 \text { e } 2 \\
380 / 2008\end{array}$ & TCU & Monitoramento & Concessão & Aneel \\
\hline
\end{tabular}

FONTE: Menezes (2010). 
Para completar a análise dos acórdãos, também foram realizadas 15 entrevistas qualitativas com parlamentares do Congresso Nacional, auditores do TCU, funcionários das agências reguladoras, diretores das empresas reguladas e funcionários dos ministérios, por meio de um roteiro de entrevista semiestruturado. As entrevistas qualitativas possibilitam ao pesquisador elucidar as condutas dos atores sociais, uma vez que, estas são mais bem interpretadas quando consideradas a partir da perspectiva dos agentes, ou seja, o sentido que eles próprios conferem às suas ações ou posições (POUPART, 2008). Desse modo, buscou-se explorar em profundidade as perspectivas dos diferentes atores sociais envolvidos com o tema da pesquisa e compreender internamente os dilemas e os argumentos desses atores.

\section{A ATUAÇÃO DO TRIBUNAL DE CONTAS DA UNIÃO: ESTUDO DE CASO DOS ACÓRDÃOS}

$\mathrm{Na}$ arena regulatória ocorre uma disputa política em torno de recursos finitos entre as empresas, o Estado, as agências e os usuários. Estes últimos, por sua baixa organização, têm seus interesses menos considerados pela regulação resultante dessa disputa. Isso se deve a um "problema de ação coletiva" clássico na literatura, resultante do grande tamanho e dispersão do grupo de usuários, o que reduz muito os incentivos à organização (OLSON, 1965).

Os Juizados Especiais Cíveis são inundados todos os meses por reclamações de usuários dos serviços regulados pelas agências reguladoras (OLIVEIRA, 2001; MENEZES, 2010). Contudo, as decisões do poder Judiciário são específicas aos processos iniciados por aqueles que acessam a Justiça. Para que os problemas apresentados pelos cidadãos-usuários sejam considerados de forma ampla pelas concessionárias, faz-se necessária a constante fiscalização e o aperfeiçoamento das regras regulatórias pelas agências reguladoras. Dessa forma, esta seção analisará em que medida o TCU, como órgão de accountability horizontal, vem atuando na arena

7 Em alguns dos casos analisados, há mais de um acórdão citado na tabela, isso porque, para o entendimento da auditoria como um todo, foi necessária a leitura complementar de outros acórdãos. regulatória para garantir que as agências regulem de maneira universalista, considerando tanto as necessidades operacionais e econômicas das empresas quanto os direitos dos usuários.

\section{V.1. Impacto da atuação do TCU sobre os usuários dos serviços regulados}

Mesmo sem criar novas regras, a fiscalização da Corte de Contas apresenta impactos significativos sobre os usuários dos serviços regulados. Ao contrário de decisões específicas do poder Judiciário em relação ao descumprimento da legislação pelas concessionárias na prestação dos serviços ao usuário, o Tribunal realiza um controle mais amplo, verificando a atuação da agência reguladora no cumprimento do seu mandato.

É possível supor que, se a agência reguladora não atuar de maneira firme no controle e na fiscalização, dificilmente as concessionárias cumprirão metas de qualidade do atendimento ou universalização do serviço, por exemplo. O controle deve ser crível para o concessionário, de modo que ele possa cumprir seu contrato de concessão e forneça um serviço de qualidade ao usuário. Nesse contexto, o Tribunal investigou o processo de universalização dos Telefones de Uso Público (TUPs) serviço pelo qual algumas concessionárias de telefonia fixa são remuneradas e responsáveis pela instalação e manutenção. No acórdão 1778 , de 2004, a Corte de Contas mostra falhas na metodologia proposta pela Anatel para realizar a fiscalização das metas estabelecidas nos contratos de concessão das empresas responsáveis pela instalação dos TUPs. Essas falhas poderiam levar as empresas a não cumprirem suas metas, uma vez que a fiscalização não parecia ser eficaz.

O setor não apresenta maiores problemas no que se refere à prestação desse serviço nas áreas urbanas. O grande desafio para as empresas é a instalação dos TUPs em áreas rurais, como em reservas indígenas e assentamentos agrícolas. Dessa forma, a partir do processo de privatização e reforma regulatória, foram estabelecidas metas de universalização do serviço de telefonia pública, com foco especial no interior do país.

O acórdão 1778 (BRASIL. TCU, 2004) mostra que, em 2004, a Anatel não possuía um cadastro completo das localidades que deveriam ser atendidas nas próximas metas de 
universalização. O cadastro existente era precário, permitindo o questionamento das metas pelas concessionárias e usuários. A principal fragilidade do cadastro era a sua forma de alimentação. As próprias empresas forneciam a informação sobre novas localidades e suas características para o sistema, chamado de Área-Área, que seria usado na fiscalização do atendimento das metas de universalização, como mostra a citação a seguir: "Independentemente do método de fiscalização das metas do PGMU, a definição do que é o universo geográfico da fiscalização das obrigações de universalização, com o grau de precisão que seja técnica e economicamente viável, é obrigação da Anatel e decorre da titularidade da mesma em avaliar o cumprimento das metas. Como pode a agência prestar contas à sociedade do cumprimento dessas metas se mesmo para uso interno esse universo não está bem delimitado?

Ademais, na prática, atualmente são as concessionárias que determinam o alcance da verificação das obrigações de universalização, uma vez que o universo de localidades do SGOU é obtido a partir do sistema Área-área, que por sua vez é alimentado pelas concessionárias. As localidades passíveis de fiscalização são as que constam deste universo, pois é a partir dele que a Anatel realiza o planejamento das fiscalizações. Esse tipo de mecanismo possibilita a existência de comportamentos indesejáveis por parte das concessionárias" (idem, p. 52).

O questionamento de fundo é que a maioria das localidades que não constava no sistema provavelmente não era atrativa comercialmente para as concessionárias que deveriam instalar os TUPs. É importante ressaltar que os TUPs, em áreas isoladas, são muito caros e pouco rentáveis para as empresas do setor de telecomunicações. Para o seu funcionamento e manutenção, faz-se necessário o uso de tecnologia específica, como a transmissão via satélite e energização solar. Além disso, é objeto freqüente de vandalismo e roubo. O TUP em área rural, dessa forma, apresenta um custo unitário muito elevado, se comparado a um TUP urbano, provido por cabos de energia e telefonia. Dessa forma, somente fiscalizações específicas da agência, a partir de um levantamento próprio de localidades, poderiam obrigar as empresas a cumprirem suas metas.

Deve-se destacar que esse método de definição de localidades, a partir da informação prestada pelas concessionárias, levou a uma grande disputa regulatória em torno do conceito de localidade, reduzindo a segurança jurídica do Processo de Universalização de Telefonia. A definição da obrigação de atendimento de uma determinada localidade por uma concessionária era definida, entre outros critérios, por seu tamanho, declarado pelas concessionárias. Cada concessionária tinha incentivos para relatar as localidades dentro da meta de Universalização das demais, mas não as localidades dentro de suas próprias metas. Mais ainda, surgiu uma disputa jurídica entre as concessionárias a respeito do método de definição do tamanho da localidade, com cada concessionária defendendo um método que reduziria a sua obrigação de Universalização, por meio da transferência de localidades para as demais. O conceito de localidade, então, tornouse disputado e ambíguo.

A má definição, pelo regulador, do conceito de localidade e do universo de localidades a serem atendidas, além da ausência de uma repartição explícita das obrigações de Universalização entre as concessionárias, reduziu fortemente a segurança jurídica e a eficácia da Universalização de Telefonia. Isso trouxe prejuízos à população mais pobre do país que vive em áreas isoladas sem acesso à comunicação. A atuação do Tribunal ocorreu para proteger essa população por meio do questionamento desse método de arrolamento de localidades, que se demonstrou inseguro para a fiscalização do cumprimento das metas. Afinal, nesse método, o fiscalizado definia o universo de fiscalização.

As fiscalizações da Anatel, mesmo com os problemas de cadastro do universo de localidades, poderiam fornecer uma maior garantia aos usuários. Na avaliação da auditoria, contudo, o método de fiscalização utilizado pela agência também apresentava graves falhas. Para uma análise mais hábil, o Tribunal contratou duas consultorias independentes, que mostraram diversos problemas metodológicos no desenho amostral desenvolvido pelo ente regulatório, particularmente uma amostra insuficiente para uma fiscalização crível do cumprimento das metas de Universalização. Em razão dessas falhas, o Tribunal determinou à Anatel que reformulasse sua metodologia de fiscalização. É importante salientar que o TCU não propôs nenhuma metodologia para essa fiscalização, apenas solicitou à agência que reformulasse as regras 
devido a problemas de natureza técnica, formalmente documentados. Dessa forma, a Corte de Contas interferiu para elevar a qualidade técnica da atuação da agência, sem determinar nenhuma direção específica sobre a decisão técnica do ente autônomo, respeitando sua prerrogativa constitucional de iniciativa regulatória. A seguir apresento as principais determinações do TCU: "9.1. determinar à Agência Nacional de Telecomunicações que: 9.1.1. apresente, em cento e oitenta dias, plano de reformulação dos processos de fiscalização das obrigações de universalização, explicitando as soluções e cronograma de implementação de ações para corrigir os seguintes pontos, destacados no relatório de auditoria deste Tribunal: 9.1.1.1. problemas relacionados à definição do universo de fiscalização (seção 5 e subseções do relatório); 9.1.1.2. problemas de amostragem (subseção 5.1.1); 9.1.1.3. intempestividade no processamento e julgamento de Procedimentos Administrativos - PADOs (subseções 5.1.3 e 5.2.3); 9.1.1.4. inadequação da estratégia de fiscalização frente à dimensão do quadro de pessoal de fiscalização (subseção 5.2.3); [...]" (idem, p. 91).

O acórdão acima apresenta duas evidências importantes. Primeiro, o TCU não determinou em seu acórdão qual deveria ser a metodologia abordada pela agência. Apenas especificou problemas que estavam afetando diretamente os usuários do setor. Segundo, há um claro impacto da atuação da Corte de Contas sobre os usuários dos serviços de telecomunicações. A partir do resultado da auditoria, a agência, de fato, iniciou um processo de revisão do "Plano Geral de Metas de Universalização" (PGMU), bem como de sua metodologia para fiscalização. Embora a agência não tenha realizado o procedimento no prazo estipulado pelo TCU, sendo finalizado somente em 2009, o novo Plano de Metas de Universalização inclui novos procedimentos para o acompanhamento das obrigações de universalização.

Os usuários do setor de energia também puderam beneficiar-se das ações do Tribunal, por meio da auditoria n. 649 de 2005 . Esse acórdão apresentou como escopo de análise a concessão de linhas de transmissão e o modelo de revisão tarifária desse segmento do setor de energia. Ao acompanhar o procedimento adotado pela Aneel para a outorga de concessão de prestação de serviço público de transmissão, o Tribunal verificou a falta de justificativas técnicas para a elaboração dos índices de preço do leilão. $\mathrm{O}$ problema mais grave apontado pelo TCU, no entanto, foi a inexistência de um processo de revisão tarifária para os serviços de transmissão. $\mathrm{Na}$ interpretação do Tribunal, sem um processo regular de revisão tarifária, a agência reguladora ficaria impedida de repassar aos consumidores os possíveis ganhos de produtividade durante o período da concessão. "ACORDAM os Ministros do Tribunal de Contas da União, reunidos em sessão do Plenário, ante as razões expostas pelo Relator, e com fundamento nos artigos $1^{\circ}$, II, e 43, I, da Lei 8.443/92 c/c a IN/TCU 27/28, em: 9.1. aprovar, com ressalvas, o primeiro estágio do presente processo de outorga; 9.2. determinar à Aneel que: 9.2.6. promova a adequação dos contratos de concessão de serviço público de transmissão de energia elétrica já assinados para incluir mecanismos destinados à redução das tarifas em razão de apropriação de ganhos de eficiência empresarial e/ou redução de custos, conforme dispõe o art. 14, inciso IV, da Lei 9.427/ 96, e para dar eficácia ao inciso VI da Primeira Subcláusula da Cláusula Terceira desses contratos [...]" (BRASIL. TCU, 2005, p. 41; sem grifos no original).

Em entrevista realizada com um assessor especial do Ministério de Minas e Energia, essa decisão foi criticada pelo entrevistado, que alegou certa "ingerência" do Tribunal, em assuntos por ele considerados técnicos e, dessa forma, de competência do ente regulatório: "Pesquisadora: De um modo geral, o Sr. acha que o TCU deveria continuar fazendo auditorias sobre as agências?

Entrevistado: Então, houve uma interferência do TCU, não vou chamar de interferência, houve uma participação ativa do TCU, numa área típica de uma agência reguladora.

A cláusula do TCU entrou no contrato, fizeram o leilão, os preços também caíram e houve um investimento. Entraram investidores. Não mudou nada. Então, quer dizer que, a gente achava que haveria instabilidade, que todo mundo iria sair correndo, o pessoal hoje entendeu bem, pensou melhor e se convenceu, que não era o correto. Nesse caso, foi positivo, não houve problemas e foi bom para todo mundo, que agora vai ver uma captura dos ganhos de eficiência dos agentes, que seria uma revisão periódica" (MENEZES, 2009a). 
No acórdão do TCU percebe-se que o ponto central da auditoria não é a criação de uma nova regra ou modificação de uma regra existente, mas o cumprimento da lei, em benefício do consumidor e das empresas. O Projeto de Lei n. 9 427, que se refere à criação da Aneel e suas atribuições, destaca que os contratos estabelecidos entre a agência e as concessionárias devem considerar a "apropriação de ganhos de eficiência empresarial e de competitividade". Entretanto, o modelo de tarifa anterior não transmitiria para o consumidor os possíveis ganhos de eficiência, tendo em vista que a tarifa seria a mesma por 15 anos, independentemente do ganho da concessionária. É importante destacar que, nos setores de infraestrutura em todo o mundo, o atual ritmo de desenvolvimento tecnológico permite ganhos de produtividade no período de cinco anos, típicos do reposicionamento tarifário, mesmo que modestos.

Pode-se argumentar que não houve a instabilidade esperada pela agência nos leilões de transmissão pelo fato de este segmento do setor elétrico ser o mais rentável (PINTO JÚNIOR, 2007). Nesse setor, o investimento é maior nos primeiros anos. Em seguida, são realizados apenas pequenos ajustes e há um período significativo em que a empresa investe apenas o mínimo necessário para a manutenção da rede. Por isso, a tarifa, no modelo original, cairia pela metade após 15 anos. Com a revisão periódica, determinada pela Corte de Contas, os usuários de energia poderão ser beneficiados com os ganhos de eficiência característicos desse segmento do setor, ao lado das concessionárias.

Ainda em relação ao setor elétrico, é importante chamar a atenção para outra auditoria, muito importante para os usuários do serviço de energia, o Acórdão n. 1066 de 2001. Este refere-se à primeira auditoria sobre a revisão tarifária dos serviços de distribuição de energia elétrica. $\mathrm{O}$ Tribunal tem atuado, de maneira significativa, na análise do processo de determinação das tarifas do setor, desde o primeiro ciclo de revisão tarifária, em 2001, da empresa Centrais Elétricas do Espírito Santo S. A. (Escelsa). O processo de revisão tarifária periódica constitui-se, basicamente, do reposicionamento tarifário e da determinação do Fator X, que será utilizado nos reajustes anuais até a próxima revisão periódica.
Segundo os auditores do Tribunal, a Aneel, no ciclo de 2001, mudou os procedimentos de cálculo tarifário, sem dar a devida publicidade aos seus atos, além de beneficiar a empresa com as modificações, em detrimento dos consumidores. As citações, a seguir, referem-se a entrevistas com auditores do TCU, em que eles justificam a intervenção da Corte de Contas no processo de revisão tarifária da agência do setor elétrico. Como pode ser observado, o Tribunal indicou a falta de publicidade dos atos da instituição reguladora e uma mudança nas regras que foi contra o preceito da modicidade tarifária, que consiste no equilíbrio das tarifas do ponto de vista dos interesses econômicos de concessionários e usuários. "Auditor 1: [...] O Tribunal não questiona a tarifa, o que ele questiona é a aplicação do marco legal. [...] É uma cortina de fumaça, do meu ponto de vista, porque dizer, "Ah, o Tribunal não pode fazer o controle da Agência relativo à tarifa", mas, não é transparência? Todo mundo quer saber como ele chegou naquele valor, daquela tarifa. Para saber como chegou, tem que saber se ele fez de forma legal e se as escolhas dele estão justificadas. Se houver justificativa, ótimo" (MENEZES, 2009b).

"Auditor 2: Para mim, é muito clara essa questão, é uma questão da Aneel fazer um processo de revisão tarifária. [...] Então, ela foi fazer os procedimentos gerais do processo de revisão tarifária. Nesses procedimentos gerais de revisão tarifária, a Aneel fez todos os estudos, de como se daria esse processo de revisão tarifária e outras questões, que foram abordadas lá, devido à particularidade do Brasil [...]. Depois, aprovou isso mediante à diretoria e deu publicidade nisso. Depois que deu publicidade, encaminhou isso ao TCU. Então, é um documento perfeito, um documento em que ela utilizou todos os procedimentos, até aquele momento. Então, naquele momento ali, ela passa a ter a ação dela vinculada, ou seja, todos os processos de revisão tarifária daquele ano vão seguir a metodologia que ela aprovou

\section{Pesquisadora: Depois a Agência mudou?}

Auditor 2: Então, ela pode até mudar, mas, desde que seja dada publicidade e aprovado, e ela não fez isso. Então, o Tribunal decretou que ela não motivou a sua alteração, e muito menos 
aprovou novamente o que deveria ser alterado, e alterou o caso concreto. Então, isso é inconstitucionalidade, na minha opinião. Ela poderia até ter alterado, mas, antes, precisava dar publicidade e ter submetido a um processo, não vou falar igual, mas, similar àquele que foi feito, originalmente. Então, nesse momento, a Aneel não atuou de forma correta. Então, com essa ação, ela pode ter causado instabilidade no mercado. Nesse caso, ela veio a prejudicar os usuários" (idem).

O mais revelador deste episódio de auditoria sobre a Aneel foi a falta de publicidade da mudança das regras. Na decisão do Acórdão n. 1066 de 2001, o Tribunal de Contas da União, ao acompanhar o processo de revisão tarifária da Escelsa, percebeu que foram elaboradas duas notas técnicas. A primeira fazia referência ao ajuste tarifário e foi elaborada seguindo procedimentos de transparência. Já a segunda nota, que revia a ação da primeira, fixando um novo valor para a tarifa de energia, foi homologada sem que houvesse oportunidade de discussão prévia na sociedade. Nesse caso, a agência deliberou sem permitir que concessionários e usuários tivessem acesso às informações pertinentes àquela ação. Em razão disto, o TCU interveio por iniciativa própria, fazendo valer seu mandato de agência de Estado para a realização de ações de controle sobre as agências reguladoras, na forma do accountability horizontal.

Durante o processo de revisão tarifária de 2001, o TCU constatou que não houve transparência no processo decisório e ocorreram falhas técnicas, que beneficiavam diretamente a empresa, em detrimento do consumidor. A Corte de Contas identificou que havia imprecisões na identificação de parâmetros que definiam o custo de capital próprio da concessionária, além da utilização do Índice Nacional de Preço ao Consumidor Amplo (IPCA) na apuração do custo real de captação de empréstimo em vez do Índice Geral de Preço do Mercado (IGP-M), como consta nos novos contratos de concessão. Com a mudança dos índices, o Tribunal observou que o custo de capital de terceiros foi superestimado para efeito de revisão tarifária, beneficiando a concessionária: "52. Deve-se observar, contudo, que o IPCA não é a taxa que indexa as tarifas de distribuição de energia elétrica e, consequentemente, as receitas dos investidores.
Os contratos de concessão estabelecem o IGPM como medida de inflação para compor o Índice de Reajuste Tarifário (IRT) (9). [...] O reajuste acumulado das tarifas da energia distribuída pela Escelsa é muito mais próximo da variação do IGPM do que da variação do IPCA. Ou seja, o IGP$M$ representa de maneira mais adequada a evolução das tarifas da Escelsa do que o IPCA.

(9) O contrato da Escelsa não explicita como se dará o processo de reajuste das tarifas, mas, os novos contratos preveem o IGP-M como indexador para os reajustes da parcela de custos gerenciáveis das distribuidoras de energia elétrica. A ANEEL está inclusive propondo o aditamento do contrato original da Escelsa para um contrato nesses moldes. Não obstante, a agência vem adotando o IPCA nos reajustes da Escelsa" (BRASIL. TCU, 2001, p. 15).

Em vista dos problemas detectados, a Corte de Contas realizou as seguintes determinações à Aneel: “[...] determinar à Aneel que, no prazo de 90 dias a contar da ciência desta: a.1.1. reavalie as ações escolhidas para cálculo do $\beta$ representativo observando o requisito de liquidez mínima dos papéis escolhidos ao longo do período de cálculo; a.1.2. recalcule o valor do $\beta$ das empresas escolhidas em relação ao mercado de referência adotado no modelo CAPM; a.1.3. justifique a adoção da distribuição arbitrada de capital de terceiros entre o Bndes e o mercado, demonstrando que tal procedimento não fere $o$ objetivo de modicidade tarifária, ou refaça os cálculos considerando a real distribuição de capital de terceiros da empresa; a.1.4. utilize o IGPM para deflacionar o custo de capital de terceiros, e adote a seqüência correta de cálculos, que resulte na projeção em termos reais do custo do capital de terceiros, e não na projeção em termos nominais para depois obter esta taxa em termos reais; a.1.5. recalcule a taxa nominal efetiva de remuneração de capital de terceiros (seção I.2.4); a.1.6. análise a pertinência das metodologias adotadas e dos valores que constam dos dois trabalhos apresentados pela Escelsa visando o ajuste da base de remuneração; a.2. caso mesmo após cumpridas todas as etapas previstas para a conclusão do novo reposicionamento tarifário da Escelsa (item 0), não tenha chegado a uma conclusão final a respeito do valor adequado para a base de remuneração da concessionária, ao optar 
por uma solução temporária, utilize o menor valor encontrado provisoriamente, até chegar a uma conclusão definitiva. a.3. proceda à ampla divulgação das notas técnicas relativas à Revisão Tarifária da Escelsa, disponibilizando-as em seu site na Internet" (BRASIL. TCU, 2001; sem grifos no original).

A fiscalização do TCU acerca da metodologia de revisão tarifária tem gerado conflitos entre a agência e a Corte de Contas. O Acórdão n. 1066 , referente ao primeiro ciclo de revisão tarifária da Escelsa, foi contestado e encontra-se suspenso, aguardando julgamento em definitivo. Além desse recurso, a Aneel também impetrou recursos referentes às decisões posteriores acerca das determinações e recomendações realizadas pelo Tribunal relacionadas ao tema de revisão das tarifas de empresas como a Cemig, Eletropaulo, Light, entre outras.

As determinações do Tribunal reduziriam as tarifas de energia para o consumidor, contudo, a instituição regulatória insiste em manter o método utilizado inicialmente, em 2001, mesmo reconhecendo que o seu procedimento apresenta falhas, como mostra a reportagem a seguir, veiculada pela imprensa: "A Aneel, agência que regulamenta o funcionamento do setor de energia, reconhece que houve um problema nas cobranças. Mas nega que o consumidor tenha sido prejudicado. Já os órgãos de defesa do consumidor querem que o consumidor receba o que teria sido pago a mais. Um prejuízo que pode chegar a $\mathrm{R} \$$ 7 bilhões. [...] Segundo o TCU, identificou-se que havia sérias distorções no modelo que a Aneel vem aplicando nos processos de reajuste tarifário das distribuidoras de energia elétrica do país. A falha metodológica remunera indevidamente as concessionárias de energia elétrica e gera prejuízos para o usuário de pelo menos $\mathrm{R} \$ 1$ bilhão ao ano" (ANEL RECONHECE ERRO, 2009).

Os acórdãos analisados nesta seção confirmam as hipóteses. Devido ao seu desenho e mandato institucional diverso, o TCU apresenta uma atuação mais universalista, se comparado às agências reguladoras, aumentando a representatividade dos cidadãos-usuários nas arenas regulatórias. Nos três acórdãos, a Corte de Contas questionou diversos critérios técnicos utilizados pelas agências dos setores de energia e telecomunicações, por meio de argumentos também técnicos. Suas ações mostraram-se importantes para que os órgãos reguladores considerassem mais os interesses do consumidor na definição da regra regulatória. No caso específico da revisão tarifária, não houve, até o presente momento, uma mudança no método de revisão, contudo, os órgãos de defesa dos consumidores parecem estar dispostos a "cobrar a conta" às concessionárias na Justiça. O resultado de uma ação judicial sobre essa matéria é uma incógnita. $\mathrm{O}$ aumento das tarifas da Eletropaulo, por exemplo, foi questionado na Justiça em 2003 e a empresa conseguiu ganhar a ação no Superior Tribunal Federal. De outro lado, é importante enfatizar que naquele momento não houve uma ampla discussão na sociedade com os diversos órgãos de defesa do consumidor mobilizando-se para requerer não a mudança no cálculo da revisão tarifária, mas a indenização do valor pago a mais.

Além disso, nota-se também, por meio das análises dos acórdãos, que o Tribunal de Contas da União tem contribuído para a construção de um ambiente regulatório mais transparente. $\mathrm{O}$ argumento central para a opção pelo modelo de agências reguladoras autônomas, no Brasil, foi a garantia da credibilidade regulatória do país ante os investidores. Essa credibilidade seria alcançada principalmente pela autonomia do ente regulador em relação aos incentivos de curto prazo do calendário eleitoral nas decisões técnicas dos setores regulados. Contudo, para que a atuação das agências reguladoras seja legítima, faz-se necessário que exista um amplo controle e transparência de suas ações. Delegação sem mecanismos de accountability é, na verdade, abdicação e antidemocrática. Nesse sentido, a fiscalização da Corte de Contas sobre as atividades fins das agências confere-lhes maior legitimidade, na medida em que aumenta a transparência do processo decisório, tanto para o investidor quanto para o usuário do serviço.

A transparência, portanto, é a primeira garantia de controle do ente autônomo. Ela permite que a sociedade civil, os concessionários e os usuários recorram contra a excessiva discricionariedade do regulador autônomo. A transparência torna a controvérsia entre autonomia e controle um falso dilema.

\section{CONCLUSÕES}

As análises em profundidade das auditorias do Tribunal de Contas da União demonstraram que as fiscalizações sobre as atividades fins das 
agências reguladoras têm contribuído para o aperfeiçoamento das regras regulatórias. A Corte de Contas mostrou-se um importante ator de controle horizontal das agências, evitando uma discricionariedade excessiva do ente regulatório na definição dos critérios da regulação. Sua atuação aumenta a segurança jurídica, já que questiona decisões das agências que não apresentam justificativas técnicas.

No que se refere aos usuários dos serviços regulados, o TCU apresenta uma atuação mais universalista, se comparada às agências reguladoras, aumentando a representatividade dos cidadãos nas arenas regulatórias. Embora o mandato das agências reguladoras seja o de uma atuação equilibrada entre os agentes econômicos e os consumidores, a relação mais próxima com as concessionárias faz que as agências regulem mais na direção das empresas, em detrimento dos usuários. Não foi possível perceber, nas análises, uma ação concreta de benefício explícito para as concessionárias, mas certo "descomprometimento" com o usuário do serviço. Por ser a parte menos informada e organizada, os consumidores não conseguem, como os concessionários, pressionar as agências por uma regulação favorável ao consumidor. Nesse sentido, a atuação do Tribunal equilibra a relação entre usuários e concessionárias, verificando os critérios das agências para definir as tarifas, a qualidade, a universalização dos serviços, entre outros.

É importante destacar também que a fiscalização da Corte de Contas não reduz a autonomia técnica da agência para deliberar acerca do conteúdo regulatório, mas torna esse processo mais transparente. Se, ao constatar um erro, o Tribunal recomenda ou determina mudanças nas decisões das agências, essa ação tem por objetivo o cumprimento da lei e do interesse público, e não substituir a agência reguladora. Desse modo, a atuação do TCU aumenta a transparência decisória, tema tão sensível ao modelo de regulação autônoma.

Por fim, a mudança institucional no arcabouço regulatório resultou em um efeito não esperado pelos reformistas da década de 1990, a saber: um aumento da presença do poder Legislativo na fiscalização das políticas públicas no Brasil. Se, antes da reforma, os setores regulados pelas agências reguladoras eram controlados pelas burocracias do poder Executivo, a partir das privatizações e da delegação de poderes às agências reguladoras, o poder Legislativo, por meio do TCU, passou a fiscalizar, de maneira mais intensa, a implementação das políticas desses setores, embora o poder Executivo continue com uma atuação mais forte.

Monique Menezes (moniquemenezes@gmail.com) é Doutora em Ciência Política pelo Instituto Universitário de Pesquisa do Rio de Janeiro (Iuperj) e Professora de Ciência Política na Universidade Federal do Piauí (UFPI).

\section{REFERÊNCIAS BIBLIOGRÁFICAS}

ABERBACH, J. 1990. Keeping a Watchful Eye: The Politics of Congressional Oversight. Washington (DC): Brooking.

BARROSO, L. R. 2006. Agências reguladoras. Constituição, transformação do Estado e legitimidade democrática. In: BNIENJOJM, G. (org.). Agências reguladoras e democracia. Rio de Janeiro: Lúmen Júris.

BOSCHI, R. \& LIMA, M. R. 2002. O Executivo e a construção do Estado no Brasil: do desmonte da era Vargas ao novo intervencionismo regulatório. In: VIANNA, L. (org.). A democracia e os três poderes no Brasil. Rio de Janeiro: IUPERJ.
BOURN, J. 2005. O papel do grupo de trabalho de privatização da INTOSAI e a responsabilização dos entes reguladores no Reino Unido. Revista do TCU, Brasília, n. 104, p. 17-22, abr.-jun.

COX, G. \& MCCUBBINS, M. 2001. The Institutional Determinants of Economic Policy Outcomes. In: HAGGARD, S. \& MCCUBBINS, M. (eds.). Presidents, Parliaments and Policy. Cambridge (UK): Cambridge University.

DINIZ, E. 1998. Uma perspectiva analítica para a reforma do Estado. Lua Nova, São Paulo, n. 45 , p. 29-48. Disponível em: http://www.scielo.br/pdf/ $\ln / \mathrm{n} 45 / \mathrm{a} 03$ n45.pdf. Acesso em: 17.set.2012. 
2001. Globalização, reforma do Estado e teoria democrática contemporânea. São Paulo em Perspectiva, São Paulo, v. 15, n. 4, p. 13-22, out.dez. Disponível em: http://www.scielo.br/pdf/spp/ v15n4/10368.pdf. Acesso em: 18.set.2012.

FIORINA, M. P. 1981. Congress Control of the Bureaucracy: A Mismatch of Incentives and Capabilities. In: DODD, L. \& OPPENHEIMER, B. (eds.). Congress Reconsider. $2^{\mathrm{a}}$ ed. Washington (DC): Congressional Quarterly.

FISCHER, L. 1981. The Politics of Shared Power: Congress and the Executive. College Station: Texas A\&M University.

GILARDI, F. 2004. Institutional Change in Regulatory Policies: Regulation Through Independent Agencies and the Three New Institutionalisms. In: JORDANA, J. \& LEVI-FAUR, D. (eds.). The Politics of Regulation: Institutions and Regulatory Reforms for the Age of Governance. Cheltenham: E. Elgar.

GOMES, E. M. 2006. As agências reguladoras independentes e o Tribunal de Contas da União: conflito de jurisdições. Revista de Administração Pública, São Paulo, v. 40, n. 4, p. 615-630, jul.ago. Disponível em: http://www.scielo.br/pdf/rap/ v40n4/31598.pdf. Acesso em: 17.set.2012.

JORDANA, J. \& SANCHO, D. 2004. Regulatory Designs, Institutional Constellations and the Study of the Regulatory State. In: JORDANA, J. \& LEVI-FAUR, D. (eds.). The Politics of Regulation: Institutions and Regulatory Reforms for the age of governance. Cheltenham: E. Elgar.

KIEWIET, R. \& MCCUBBINS, M. 1991. The Logic of Delegation: Congressional Parities and the Appropriation Process. Chicago: University of Chicago.

LODGE, M. 2004. Accountability and Transparency in Regulation: Critiques, Doctrines and Instruments. In: JORDANA, J. \& LEVI-FAUR, D. (eds.). The Politics of Regulation: Institutions and Regulatory Reforms for the Age of Governance. Cheltenham: E. Elgar.

LOWI, T. 1979. The End of Liberalism: the Second Republic of the United States. New York: Norton.

LUPIA, A. \& MCCUBBINS, M. 1998. The Democratic Dilemma: Can Citizens Learn What the Need to Know? Cambridge (UK): Cambridge University.

MCCUBBINS, M. \& SCHWARTZ, T. 1984. Congressional Oversight Overlooked: Police
Patrols versus Fire Alarms. American Journal of Political Science, Bloomington, v. 28, n. 1, p. 165-179, Feb. Disponível em: http://www.unc.edu/ $\sim$ fbaum/teaching/PLSC541_ Fall08mcubbins_ schwartz_1984.pdf. Acesso em: 28.set.2012.

MELO, M. 2000. Política regulatória: uma revisão da literatura. $B I B$, Rio de Janeiro, n. 50, p. 7-44.

2001. A política regulatória: responsabilização, credibilidade e delegação. Revista Brasileira de Ciências Sociais, São Paulo, v. 16, n. 46, p. 55-68, jun. Disponível em: http:// www.scielo.br/pdf/rbcsoc/v16n46/a03v1646.pdf. Acesso em: 17.set.2012.

MENEZES, M. 2004. Desenho institucional e mudança regulatória no Brasil. Rio de Janeiro. Dissertação (Mestrado em Ciência Política). Instituto Universitário de Pesquisa do Rio de Janeiro.

2005. O modelo de regulação independente brasileiro. In: INSTITUTO TENDÊNCIAS DE DIREITO E ECONOMIA. Agências reguladoras mercados de capitais, energia elétrica e petróleo. São Paulo: Bovespa.

2009a. Entrevista com assessor especial do Ministério de Minas e Energia. Digit.

2009b. Entrevistas com auditores do Tribunal de Contas da União. Digit.

2010. Autonomia e controle das agências reguladoras: o papel do Tribunal de Contas da União no arranjo regulatório brasileiro. Rio de Janeiro. Tese (Doutorado em Ciência Política). Instituto Universitário de Pesquisa do Rio de Janeiro.

MOE, T. 1984. The New Economics of Organization. American Journal of Political Science, Bloomington, v. 28, n. 4, p. 739-777, Nov.

1987. Congressional Control of the Bureaucracy: An Assessment of the Positive Theory of "Congressional Dominance". Legislative Studies Quarterly, Iowa, v. 12, n. 4, p. 475-520, Nov.

O'DONNELL, G. 1994. Delegative Democracy. Journal of Democracy, Baltimore, v. 5, n. 1, p. 5569. Disponível em: http://muse.jhu.edu/login? auth=0\& type $=$ summary \&url=/journals/ journal_of_democracy/v005/5.1odonnell.pdf. Acesso em: 18.set.2012.

OLSON, M. 1965. The Logic of Collective Action. Cambridge (MA): Harvard University. 
PESSANHA, C. 1997. Relações entre os poderes Executivo e Legislativo no Brasil: 1946-1994. São Paulo. Tese (Doutorado em Ciência Política). Universidade de São Paulo.

PINTO JÚNIOR, R. P. S. 2007. Perdas e adicionais de receita no mercado de transmissão de energia elétrica. Trabalho apresentado no II Seminário Internacional do Grupo de Estudo do Setor Elétrico (Gesel), realizado no Rio de Janeiro de 13 a 14 de setembro. Digit.

POUPART, J. 2008. A entrevista de tipo qualitativo: considerações epistemológicas, teóricas e metodológicas. In: POUPART, J.; DESLAURIERS， J-P.; GROULX, A.; LAPERRÈRE, R. M. \& PIRES, A. A pesquisa qualitativa: enfoques epistemológicos e metodológicos. Petrópolis: Vozes.
PRZEWORSKI, A. 2003. States and Markets: A Primer in Political Economy. Cambridge (UK): Cambridge University.

SALGADO, L. H. 2003. Agências reguladoras na experiência brasileira: um panorama do atual desenho institucional. Brasília: Instituto de Pesquisa Econômica Aplicada.

SALGADO, L. H. \& MOTTA, R. 2005. Marcos regulatórios no Brasil: o que foi feito e o que falta fazer. Rio de Janeiro: Instituto de Pesquisa Econômica Aplicada.

WEINGAST, B. 2005. Caught in the Middle: The President, Congress, and the PoliticalBureaucratic System. In: ABERBACH, J. \& PETERSON, M. (eds.). Institution of American Democracy: Executive Branch. Oxford: Oxford University.

\section{OUTRASFONTES}

Aneel reconhece erro em cobrança de contas de luz. 2009. Globo.com, 23.out. Disponível em: http:// g1.globo.com/bomdiabrasil/0,,MUL135190316020,00-ANEEL+RECONHECE+ERRO+ EM+COBRANCA+DE+CONTAS+DE+LUZ.html. Acesso em: 18.set.2012.

BRASIL. TCU. 2001. Acórdão n. 1 066/2001 - TCU - Plenário. Brasília: Tribunal de Contas da União. 2004. Acórdão n. 1 778/2004 - TCU -
Plenário. Brasília: Tribunal da Contas da União. 2005. Acórdão n. 649/2005 - TCU Plenário. Brasília: Tribunal de Contas da União.

OCDE. 2008. Relatório sobre a reforma regulatória: Brasil fortalecendo a governança para o crescimento. Disponível em: http:// www.sinagencias.org.br/conteudo_arquivo/ 220708_4AE8D5.pdf. Acesso em: 18.set.2012. 
This document was created with Win2PDF available at http://www.win2pdf.com. The unregistered version of Win2PDF is for evaluation or non-commercial use only. This page will not be added after purchasing Win2PDF. 